\title{
Laparoscopic Surgery in COVID-19 Era in a Tertiary Hospital in Nepal
}

\author{
Ghanashyam Thapa ${ }^{1}$, Bikash Nepal ${ }^{1}$
}

${ }^{1}$ Department of Surgery, Bir Hospital, Kathmandu, Nepal

\section{ABSTRACT}

Introduction: There is great concern and risk of transmission of COVID-19 infection from the aerosolized smoke during laparoscopic surgery although there is a lack of enough literature to prove this. To minimize these risks and get the benefit of laparoscopic surgery, we used a low-cost filtration system connected to an underwater seal bag filled with a $5 \%$ sodium hypochlorite solution.

Materials and Methods: This is a retrospective study of prospectively maintained data of cases of laparoscopic surgeries using a low-cost filtration device system connected with an underwater seal bag filled with 5\% sodium hypochlorite solution. Use of personal protective equipment, minimal staff in operative theatre, preoperatively testing of patients before admission for surgery was done. During surgery, minimal use of electrocautery in low power setting maintaining low pneumoperitoneum and cautious desufflation of smoke during and end of the procedure from one of the trocars fitted to heat and moisture exchanger Filter, connected through a tube to $5 \%$ sodium hypochlorite solution in underwater seal bag, was performed.

Results: During the lockdown from May 2020 to October 2020, 41 elective laparoscopic surgeries were done. All patients were tested negative before the procedure. No staff in operation theatre developed symptoms of COVID-19 or tested positive for COVID-19 infection for up to 2 weeks period.

Conclusions: In this Pandemic situation, we have to co-habit with this SARS-Cov-2 virus. Minimally invasive surgeries can be continued with safety measures with modifications like the use of low-cost filtration devices for smoke filtration and evacuation.

\section{Correspondence:}

Dr. Ghanashyam Thapa, MBBS, MS

Assistant Professor, Department of Surgery, Bir Hospital, NAMS, Nepal

ORCID ID: 0000-0001-9363-4480

Email: saudagi9@gmail.com

Submitted: $2^{\text {nd }}$ November 2020

Accepted: $18^{\text {th }}$ December 2020

Source of Support: None

Conflict of Interest: None

Citation: Thapa G, Nepal B. Laparoscopic Surgery in COVID-19 Era in a Tertiary Hospital in Nepal. NMJ 2020;3(2):356-60. DOI 10.3126/nmj.v3i2.34667

Keywords: COVID-19; HME Filters; Laparoscopy; Sodium hypochlorite

\section{INTRODUCTION}

After the first case of COVID-19 was reported in the Hubei Province of China on $31^{\text {st }}$ December 2019, it was declared Pandemic by WHO on $11^{\text {th }}$ March $2020 .^{1}$ The first case of covid-19 was detected in Nepal on $23^{\text {rd }}$ January 2020 in a 32-year old Nepali man returning from Wuhan. ${ }^{2}$ Nepal imposed a strict first full lockdown on March 24, 2020, which was extended to $14^{\text {th }}$ June 2020 to contain the COVID-19 outbreak. $^{3}$

Surgery in the COVID era has been limited to emergency and semi-emergency oncologic surgeries. As per guidelines, elective surgeries should be postponed. Surgery for COVID positive patient can be postponed until the patient is tested negative.
We must cohabit with the Nobel Coronavirus until vaccines are available, so surgery should be done with safety measures. The most important thing is the patient testing before the surgery. Most centers recommend nasopharyngeal swab polymerase chain reaction (PCR) at admission, monitoring of body temperature during hospital admission, to ensure that patient is asymptomatic a week before surgery and is not in contact with a COVID-19 case in the last 2 weeks. Protection of staff in operation theatre (OT) is ensured by the use of PPE by all staff, minimum use of staff and people not directly involved in the operation, and curtailing training activities. ${ }^{4-7}$ 
The main issues in laparoscopy in the COVID-19 era are the hazards within the surgical smoke and aerosol. The creation of pneumoperitoneum with the use of electrocautery for more than 10 minutes makes laparoscopy an aerosol-generating procedure. ${ }^{8,9}$ There is a risk of aerosol exposure to operation theatre staff during instrument introduction, change, removal, specimen extraction, and desufflation. The increased pressure in pneumoperitoneum and sudden release of surgical smoke in pressurized $\mathrm{CO}_{2}$ during desufflation poses more risks than open surgery. The use of energy devices causes aerosolisation of virus-infected tissues to as small as $0.07-0.42$ microns by electrocautery, $0.1-0.8$ microns by laser ablation, and 0.35 to 6.5 microns by an ultrasonic scalpel. ${ }^{7,10}$ In general low temperature from commonly used energy devices in laparoscopy surgery cannot deactivate the virus cellular components. There has been evidence of activated virus of Human Immuno Virus (HIV), Hepatitis B in surgical smoke while operating on them and there is evidence of transmission to surgical staff from surgical smoke during an aerosol-generating procedure like surgery. The same is expected in surgical smoke of the Nobel coronavirus. One recent paper suggested that SARSCOV-2 has been found to be viable in aerosol for 3 hours and on surfaces for up to $72 \mathrm{hrs}^{7,11,12}$

Despite the guidance of surgical care by the Royal College of Surgeons of Edinburgh to avoid laparoscopy, using a filtration and evacuation system for pneumoperitoneum gases, smoke contamination can be avoided. Steps like instrument cleaning during surgery, releasing pneumoperitoneum before removing trocars as advised by a paper by Zheng et al in their Chinese and Italian experience can be followed. Different types of filtration devices like high-efficiency particulate air ( HEPA) filters, Ultralow particulate air (ULPA) filters can be used which can filter bacterial and viral particles effectively like $99.99 \%$ filtration capacity of HBV and HCV of diameter 42 and 30-60 nm respectively. HEPA filters can filter larger than 0.3 microns and ULPA can retain 0.1 microns at an efficiency of $99.9 \%$. As the diameter of the SARS-CoV-2 virus is 70 to $90 \mathrm{~nm}$, this filtration

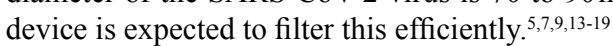

Society of European Gynaecological Surgery advised for maintaining abdominal pressure less than $10 \mathrm{mmHg}$ for Robotassisted, 10-15 mmHg for conventional Laparoscopy with filter for aerosol and smoke evacuation, minimal cautery use with low electrosurgery unit's settings, perioperative cleaning of instruments, minimal use of staffs for minimizing transmission of SARS-CoV-2.7, ${ }^{7,15,20,21}$

Underwater seal evacuation of surgical smoke immersed under heated water has been advised as a cheap option for desufflation. ${ }^{22}$ Virucidal effects of disinfectants like households bleach 1:49 and 1:99 titre have been demonstrated with non-detection of the virus titre at 5 mins, 15 mins, and 30 mins. ${ }^{23,24}$ Instead of Heated water, an underwater seal container containing $4 \%$ sodium hypochlorite solution has also been recommended for the evacuation of smoke during laparoscopic surgery. ${ }^{25,26}$

So this study was aimed to observe the effects of the use of filtration System (Heat and Moisture exchanger (HME) filter along with desufflation in underwater seal bag containing $5 \%$ sodium hypochlorite solution) in laparoscopic surgery on surgery staffs to reduce the cross-contamination and transmission of covid-19.

\section{MATERIALS AND METHODS}

This study was conducted in the Department of General Surgery in Bir Hospital from March 2020 to October 2020. This is a cross-sectional retrospective observational cohort study done of prospectively maintained data of all patients undergoing laparoscopic surgery. All Laparoscopic surgeries conducted either elective or emergency during this period were included. This study was performed to study the impact of laparoscopic surgery with safety measures on the transmission of COVID infection to patients and staff. Statistical Package for Social Sciences (SPSS, Inc., Chicago, Illinois) version 16.0 was used to confirm the statistical significance of the data obtained. Continuous data are presented as mean \pm Standard Deviation (SD). Categorical data are presented as proportions.

Each intervention was performed by high-experienced surgeons with only essential personnel in the operating room, with the suspension of unnecessary training and mentoring activities. Personal Protective Equipment (PPE) was used by staff and patients according to hospital regulations. For COVID negative cases, only N95 masks and face shields were worn by the scrubbed teams. For all status unknown cases, all staff used PPEs. Minimum OT staff were used. Patients were tested with a nasopharyngeal swab PCR for COVID-19 at admission and all the department staff were tested weekly as per the hospital policy. Operating Theatre was maintained at negative pressure.

During the procedure, A HME filter was attached to the $\mathrm{CO}_{2}$ insufflator, which was connected to a Hasson port (fig.1). After ports were placed, valves of all ports were closed; one of the ports was attached to a tube connected to an HME filter which was again fitted to an underwater seal bag filled with $5 \%$ sodium hypochlorite solution. The suction cannula was connected to a disposable suction bag filled with $5 \%$ sodium hypochlorite solution. Minimal use of electrocautery was done. During the procedure and after the procedure, $\mathrm{CO}_{2}$ was released from the port connected to a filter (fig. 2).

After the procedure was finished, ports were closed as usual and the system of connecter with filter and the disposable suction bag was disposed.

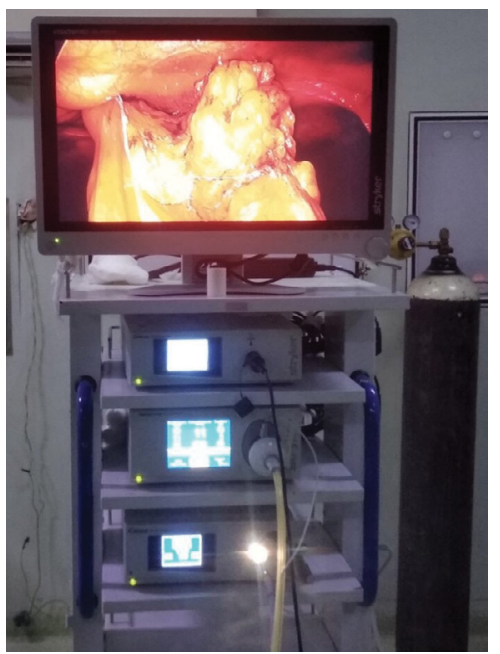

Figure 1: HME filter was connected to a gas insufflator 


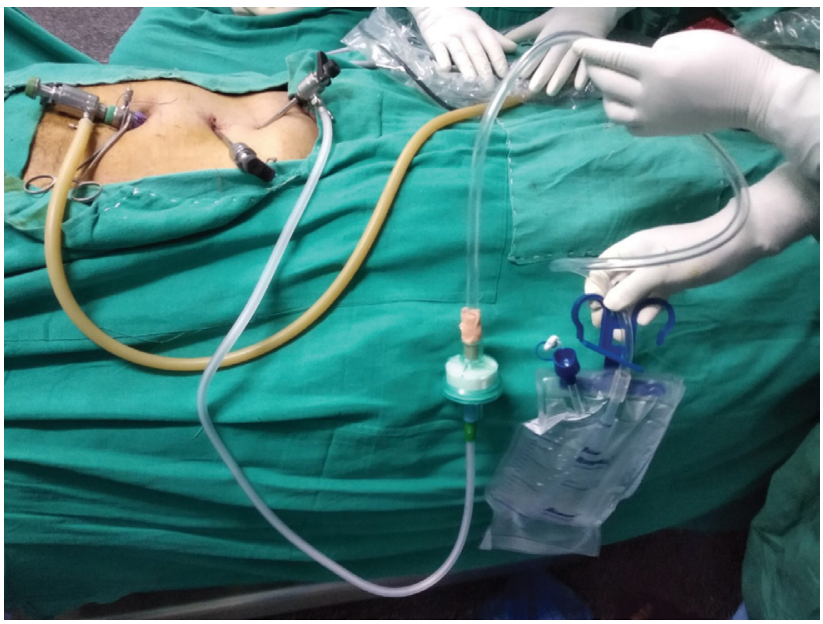

Figure 2: Trocar was connected with a tube to a HME filter which was again connected to an underwater seal bag filled with $5 \%$ Sodium Hypochlorite solution.

\section{RESULTS}

There were a total of 41 patients. The mean age of patients is 42 years. The female population contributed to $63.4 \%$ whereas the male population contributed to $36.6 \%$. The major bulk of surgery involved Cholelithiasis (63\%) followed by Ventral Hernia (12\%), Inguinal Hernia (19.5\%), and Gall Bladder polyp (4.9\%). (Table 1)

Table 1: Demographic Parameters of the study population $(n=41)$

\begin{tabular}{ll}
\hline Age(years),mean \pm SD ( Range) & $\mathbf{4 2 . 1 2} \pm \mathbf{1 3 . 6 2} \mathbf{( 1 9 - 7 7 )}$ \\
\hline Sex ratio Male : Female & $15: 22$ \\
\hline ASA score $>=\mathbf{3}$ & 3 \\
\hline Indications for surgery & 26 \\
\hline Cholelithiasis & 5 \\
\hline Ventral Hernia & 8 \\
\hline Inguinal Hernia & 2 \\
\hline GB polyp & \\
\hline
\end{tabular}

SD-Standard Deviation; ASA- American Society of Anesthesiologists class; GB -Gall Bladder

Laparoscopic cholecystectomy (68.3\%) was the most common surgical procedure done followed by LVHR (12.2\%), TEP $(14.6 \%)$, and TAPP $(4.9 \%)$. (Table 2) There was no inadvertent evacuation of smoke. The mean duration of surgery was 68.85 minutes. There were no major complications postoperatively. The mean duration of hospital stay was 2.4 days. None of the patients and OT staff developed COVID infection within 2 weeks of surgery. (Table 3 )

Table 2: Types of Surgical Procedure among the study population $(n=41)$

\begin{tabular}{ll}
\hline Types & Frequency (\%) \\
\hline Laparoscopic cholecystectomy & $28(68.3)$ \\
\hline Laparoscopic Ventral Hernia Repair (LVHR) & $5(12.2)$ \\
\hline Total extraperitoneal Repair (TEP) & $6(14.6)$ \\
\hline Transabdominal Preperitoneal Repair (TAPP) & $2(4.9)$
\end{tabular}

Table 3: Intraoperative and post-operative Parameters

\begin{tabular}{ll}
\hline Inadvertent smoke evacuation event & Nil \\
\hline Duration of surgery (minutes),mean \pm SD (Range) & $\begin{array}{l}68.85 \pm 16.99 \\
(50-120)\end{array}$ \\
\hline Complications Clavin Dindo grade I or II & 2 \\
\hline Mean duration of Hospital stay (days) & 2.4 \\
\hline Post-operative Covid Positive status of Patient & Nil \\
\hline $\begin{array}{l}\text { Covid Positive Status of OT staffs within 2 weeks of } \\
\text { operation }\end{array}$ & Nil \\
\hline
\end{tabular}

\section{DISCUSSION}

The use of energy devices causes aerosolisation of virus-infected tissues to as small as 0.07-0.42 microns by electrocautery, 0.1-0.8 microns by laser ablation, and 0.35 to 6.5 microns by an ultrasonic scalpel. ${ }^{7,10}$ Sudden release of surgical smoke in pressurized $\mathrm{CO}_{2}$ during desufflation and instrument change poses the risk of exposure of aerosol to operation theatre staff. ${ }^{15}$

The surgical smoke during laparoscopy can harbor certain viruses like Hepatitis B Virus (HBV) in HBV positive patient. ${ }^{11}$ There has been an occurrence of transmission of Human papillomavirus (HPV) virus from smoke from electrocautery in 4 health personnel with the development of HPV related cancers. ${ }^{27}$ In cases of surgery of HBV positive case, smoke have found to contain HBV virus in laparoscopic surgery in a study done by Kwak et al. Ten out of 11 patients with HBV undergoing laparoscopic or robotic surgeries had HBV virus in smoke, however, no transmission to health personnel from smoke have been documented yet. ${ }_{11,28-30}$ SARS Cov-2 virus was found in higher concentration in the peritoneal fluid than respiratory tract. ${ }^{31,32}$ Transmission of COVID-19 infection from surgical smoke during electrocautery use in laparoscopy of COVID positive patient has not been reported so far. ${ }^{27,31-34}$

Our study showed that no OT staff were affected with SARSCov-2 with the use of personal protection by OT staff and use of HME filter for smoke evacuation and desufflation connected with underwater seal bag filled with 5\% sodium hypochlorite solution. Similarly in his study, Giovanni Motterie et al performed 77 minimal invasive surgeries with 62 robotic and 15 laparoscopic procedures during the lockdown in Italy. All procedures were done by experienced surgeons with the use of PPE and adopting strategies to prevent the smoke formation and spread of pneumoperitoneum. No staff was tested positive during the period. ${ }^{20}$ Similar to our study, Somashekhar et al demonstrated safe laparoscopic surgery using an extra port trocar for smoke evacuation during laparoscopy, which was connected with tubing to a water seal container containing $4 \%$ sodium hypochlorite solution. ${ }^{25}$

Pawar et al performed 12 colorectal cancer surgeries by laparoscopic methods by using HEPA filter in all COVID positive patients using full PPE. He reported that laparoscopic surgery can be safely performed. ${ }^{35,36}$ Similarly Galvez A did laparoscopic surgery for perforated peptic ulcer in a patient having COVID -19 pneumonia with use of PPE and HEPA filter. Operation theater staff did not contract COVID -19 infection. ${ }^{37}$

Another study by Dhaivat et al demonstrated 24 safe laparoscopic surgeries with a closed smoke evacuation/filtration system using 
an ultra low-particulate air (ULPA) filtration capability. Surgery was done for either emergency or semi-urgent cases in 17 males and 7 females. Low intra-abdominal pressure was maintained during all laparoscopic surgeries. The mean duration of surgery was 58 minutes. Compliance of operation theatre staff was high due to this deemed safe smoke evacuation system. ${ }^{38}$

Zago et al described two types of configurations of connections using the same type of HME filter while performing laparoscopic surgery and during desufflation. They recommended the shortest length of connection from the trocar to the filter. In their study, 49 laparoscopic surgeries were done, 8 patients had COVID infection preoperatively, 9 had it postoperatively. No operating room personnel had illness consistent with covid or became covid positive. ${ }^{9}$

\section{CONCLUSIONS}

The available data shows that laparoscopic surgeries can be performed with some system modifications. Personal protection with PPE, minimal use of staff, and preoperatively testing of patients for SARS-Cov-2 should generally be done. Use of lowcost filtration systems with trocars connected to HME Filters which is again connected to underwater seal bag filled with hypochlorite solution can be recommended with special attention to a minimal use of cautery in low power settings and lowering of pneumoperitoneum.

\section{REFERENCES}

1 Cucinotta D, Vanelli M. WHO Declares COVID-19 a Pandemic. Acta Biomed. 2020;91(1):157-60. $\underline{\text { Crossref }}$

2 Bastola A, Sah R, Rodriguez-Morales AJ, Lal BK, Jha R, Ojha HC, etal. The first 2019 novel coronavirus case in Nepal. The Lancet Infectious Diseases. 2020; 20: 279-80. Crossref

3 Pradhan TR. Nepal goes under lockdown for a week starting 6 am Tuesday. The Kathmandu Post. March 30, 2020. (Accessed on 29 May 2020) Available from: Website

4 Francis N, Dort J, Cho E, Feldman L, Keller D, Lim R, et al. SAGES and EAES recommendations for minimally invasive surgery during COVID-19 pandemic. Surg Endosc. 2020;34(6):2327-31. Crossref

5 The Royal College of Surgeons. Updated Intercollegiate General Surgery Guidance on COVID-19 2020; Available from: Website

6 AMASI (Association of Minimal Access Surgeons of India). AMASI guideline for conducting minimal access surgery during COVID-19 pandemic. 2020. (Accessed 19 Apr 2020) Available from: Website

7 Zheng MH, Boni L, Fingerhut A. Minimally Invasive Surgery and the Novel Coronavirus Outbreak: Lessons Learned in China and Italy. Ann Surg. 2020;272(1):e5-e6. Crossref

8 Angioni S. Laparoscopy in the coronavirus disease 2019 (COVID-19) era. Gynecol Surg. 2020;17(1):3. Crossref

9 Zago M, Uranues S, Chiarelli ME, Grandi S, Fumagalli LA, Tavola $\mathrm{M}$, et al. Enhancing safety of laparoscopic surgery in COVID-19 era: clinical experience with low-cost filtration devices. Eur J Trauma Emerg Surg. 2020;46(4):731-5. $\underline{\text { Crossref }}$

10 Alp E, Bijl D, Bleichrodt RP, Hansson B, Voss A. Surgical smoke and infection control. J Hosp Infect. 2006;62(1):1-5. Crossref

11 Kwak HD., Kim SH., Seo YS., Song KJ. Detecting hepatitis B virus in surgical smoke emitted during laparoscopic surgery. Occup Environ Med. 2016;73:857-63. Crossref

12 Van Doremalen N, Bushmaker T, Morris DH, Holbrook MG, Gamble A, Williamson BN, et al. Aerosol and surface stability of SARSCoV-2 as compared with SARS-CoV-1. N Engl J Med. 2020 Crossref

13 Dellamonica J, Boisseau N, Goubaux B, Raucoules-Aimé M. Comparison of manufacturers' specifications for 44 types of heat and moisture exchanging filters. Br J Anaesth 2004; 93:532-9. Crossref

14 Baron S, Fons M, Albrecht T. Viral Pathogenesis. In: Baron S, ed. Medical Microbiology. Galveston, TX: University of Texas Medical Branch at Galveston; 1996.

15 El Boghdady M, Ewalds-Kvist BM. Laparoscopic Surgery and the debate on its safety during COVID-19 pandemic: A systematic review of recommendations. The Surgeon. 2020;S1479-666X(20)30104-9. Crossref

16 To KKW, Tsang OTY, Leung WS, Tam AR, Wu TC, Lung DC. Temporal profiles of viral load in posterior oropharyngeal saliva samples and serum antibody responses during infection by SARSCoV-2: an observational cohort study. Lancet Infect Dis. 2020;20:56574. $\underline{\text { Crossref }}$

17 Mowbray NG, Ansell J, Horwood J, Cornish J, Rizkallah P, Parker A et al. Safe management of surgical smoke in the age of COVID-19. Br J Surg 2020; 107: 1406-13. Crossref

18 AORN Guideline summary: surgical smoke safety. AORN J. 2017;105:498-500. Crossref

19 Nelson Laboratories Inc. Sodium chloride aerosol testing of breathing system filters (BSF). Lab No. 399951A. 1 Amended. 2008.

20 Motterle G, Dal Moro F, Zanovello N, Morlacco A, Boemo DG, Zattoni F, Zattoni F. Minimally invasive urologic surgery is safe during COVID-19: experience from two high-volume centers in Italy. J Robot Surg. 2020;14(6):909-11. Crossref

21 Kimmig R, Verheijen RHM, Rudnicki M; for SERGS Council. Robot assisted surgery during the COVID-19 pandemic, especially for gynecological cancer: a statement of the Society of European Robotic Gynaecological Surgery (SERGS). J Gynecol Oncol. 2020;31(3):e59. 10.3802/jgo.2020.31.e59.

22 Hamed H. Underwater-seal evacuation of surgical smoke in laparoscopy during the COVID-19 pandemic: A feasibility report of a simple technique. Br J Surg. 2020;107(13):e640-e641. Crossref

23 Chin AWH, Chu JTS, Perera MRA, Hui KPY, Yen HL, Chan MCW, et al. Stability of SARS-CoV-2 in different environmental conditions. Lancet Microbe. 2020;1(1):e10. Crossref

24 Dev Kumar G, Mishra A, Dunn L, Townsend A, Oguadinma IC, 
Bright KR, Gerba CP. Biocides and Novel Antimicrobial Agents for the Mitigation of Coronaviruses. Front Microbiol. 2020;11:1351. $\underline{\text { Crossref }}$

25 Somashekhar SP, Inamdar MB, Manjiri S,Talwar S, Acharya RP, Ashwin KR, et al. Minimally Invasive Surgery and Surgical Smoke, Decoding Fear and Ensuring Safety: Adaptations and Safety Modifications During COVID Pandemic. Indian J Gynecol Oncol. 2020;18(3):96. Crossref

26 IASO (Indian Association of Surgical Oncology). Updated IASO Covid-19 guidelines. (Accessed 16 Apr 2020) Available from: Website

27 Liu Y, Song Y, Hu X, Yan L, Zhu X. Awareness of surgical smoke hazards and enhancement of surgical smoke prevention among the gynecologists. J Cancer. 2019 ;10(12):2788-99. Crossref

28 Sood AK, Bahrani-Mostafavi Z, Stoerker J, Stone IK. Human papilloma virus DNA in LEEP plume. Infect Dis Obstet Gynecol. 1994;2:167-70. Crossref

29 Zhou Q, Hu X, Zhou J, Zhao M, Zhu X, Zhu X. Human papillomavirus DNA in surgical smoke during cervical loop electrosurgical excision procedures and its impact on the surgeon. Cancer Manag Res. 2019;11:3643-54. Crossref

30 Limchantra IV, Fong Y, Melstrom KA. Surgical smoke exposure in operating room personnel: a review. JAMA Surg $2019 ; 154(10): 960-$ 7. $\underline{\text { Crossref }}$

31 Barberis A, Rutigliani M, Belli F, Ciferri E, Mori M, Filauro M et al. SARS-Cov-2 in peritoneal fluid: an important finding in the Covid-19 pandemic. Br J Surg 2020; 107: e376-6. Crossref
32 Coccolini F, Tartaglia D, Puglisi A, Giordano C, Pistello M, Lodato M, Chiarugi M. SARS-CoV-2 is present in peritoneal fluid in COVID-19 patients. Ann Surg 2020; 272: e240-2. Crossref

33 Al-Balas M, Al-Balas HI, Al-Balas H. Surgery during the COVID-19 pandemic: a comprehensive overview and perioperative care. Am J Surg. 2020;219(6):903-6. Crossref

34 Diaz A, Sarac Benjamin A, Schoenbrunner Anna R, Janis Jeffrey E, Pawlik Timothy M. Elective surgery in the time of COVID-19. Am J Surg. June 2020;219(6):900-2. $\underline{\text { Crossref }}$

35 Pawar T, Pokharkar A, Gori J, Pandey D, Rohila J, Dsouza A, Saklani A. The Technique and Justification for Minimally Invasive Surgery in COVID-19 Pandemic: Laparoscopic Anterior Resection for Near Obstructed Rectal Carcinoma. J. Laparoendosc. Adv. Surg. Tech. 2020;30:485-7. rossref

36 Serban D, Smarandache CG, Tudor C, Duta LN, Dascalu AM, Aliuș C. Laparoscopic Surgery in COVID-19 Era-Safety and Ethical Issues. Diagnostics (Basel). 2020;10(9):673. Crossref

37 Galvez A, King K, El Chaar M, Claros L. Perforated Marginal Ulcer in a COVID-19 Patient. Laparoscopy in these Trying Times? Obes Surg. 2020;30(11):4605-8. Crossref

38 Vaishnav D, Patel B. Laparoscopic Gastrointestinal Surgery During COVID-19 Pandemic: Single-Center Experience. J Laparoendosc Adv Surg Tech A. 2020 Aug 24. $\underline{\text { Crossref }}$ 